\title{
TH wt Allele
}

National Cancer Institute

\section{Source}

National Cancer Institute. TH wt Allele. NCI Thesaurus. Code C127895.

Human TH wild-type allele is located in the vicinity of $11 \mathrm{p} 15.5$ and is approximately $8 \mathrm{~kb}$ in length. This allele, which encodes tyrosine 3-monooxygenase protein, is involved in tyrosine metabolism. Mutation of the gene is associated with autosomal recessive Segawa syndrome. 